\title{
RAP1A wt Allele
}

National Cancer Institute

\section{Source}

National Cancer Institute. RAP1A wt Allele. NCI Thesaurus. Code C52607.

Human RAP1A wild-type allele is located in the vicinity of 1p13.3 and is approximately 174

$\mathrm{kb}$ in length. This allele, which encodes Ras-related protein Rap-1A, is involved in the suppression of the mitogenic activity of Ras family GT Pases. 